\title{
Definition of the System Yield Table
}

\author{
Yukichi Konohira*
}

\begin{abstract}
A project study on the development of new type of yield table has been carried out since 1989. The result of this study was reported as "System Yield Table" in 1992 and "Programs of System Yield Table" in 1995. This report discusses the question "What is the system yield table ?" by overviewing programs developed. The yield table of the type used widely for Japanese forest management and forest planning to date since the 19th century is called a "conventional yield table". The conventional normal yield table or empirical yield table shows the estimated values of forest stand growth, in case of specific tree species in a specific area and under specific management as variables of site, stand age and density. This is called the yield table of the first generation. A growth diagram of the stand prepared with the density effect of the stand as a basis is called a "forest stand density-control diagram". This diagram shows relationship corresponding to stand density, volume, tree height and diameter in the growth process of the stand on the plane. This can estimate the yield in the case of various density-controls. The conventional yield table of the first generation was line information on growth, while this density-control diagram would be plane information on growth, and is called the "yield table of the second generation".

The basic characteristic of the system yield table is that it is a computer-program with an algorithm to estimate the growth process in the future in cases of various types of management for the forest stand under various conditions. The system yield table can express countless growth processes in countless stands in a multidimensional space formed by variables including tree diameter, height, volume, density, tree age, thus it is called the third generation yield table to indicate the whole space. Evaluation shall be made for the function level of the system yield table by explaining the condition of the forest stand, management method and growth process. Functions are explained by the following four items.

(1) Quantity and quality of information on estimating forest stand condition, management and growth (information quantity).

(2) Range of applicable forest stand (applicable range).

(3) Usability of system yield table program (easiness of use).

(4) Rationality of growth model used for estimation (logic).

Keyword: yield prediction, yield table, growth model.
\end{abstract}

\section{INTRODUCTION}

Since April, 1989, a joint study on the "Preparation of a System Yield Table" has been carried out by 23 participants from 16 organizations. The result of this study was reported as "System Yield Table" in March, 1992. Follow-

* Faculty of Agriculture, Tokyo University of Agriculture and Technology, 3-5-8 Saiwai-cho, Fuchu, Tokyo 183 Japan ing this, a project study aiming at the development of a practical program commenced in April, 1992. Through studies carried out over the past 6 years, the technical term "system yield table" has been used, and as a result of explaining its concept, "citizenship" is now being obtained to some extent among forest planning specialists. This report discusses the question "What is the system yield table ?" by overviewing programs developed thus far.

J. For. Plann. 1:63-67 (1995) 


\section{CONVENTIONAL YIELD TABLE}

\section{Yield Table of the First Generation}

The yield table of the type used widely for Japanese forest management and forest planning to date since the 19 th century is called a "conventional yield table". In comparison with this, a table with different types, functions and meaning is called a "system yield table". The main points of the conventional yield table will be summarized briefly below:

The conventional normal yield table or empirical yield table shows the estimated values of forest stand growth, in case of specific tree species in a specific area under a specific management as variables of site, stand age and density (NAGumo and Minowa 1990). As standards, stand volume and tree-number classified by major and sub tree, growing stock, average diameter, average height of stand are displayed for 5 year periods. This format commenced in the $1890 \mathrm{~s}$, and the format or development methods have been unified for national forests (MizUTA 1977). In the $1950 \mathrm{~s}$, in particular, it was systematically developed on Japanese representative plantation tree species in each area (MIURA 1967).

The applications are estimation of yield in the future, judgment of management result, forestation policy and judgment of the site. This table has played a vital role as a basis for the calculation of standard cutting volume (allowable cutting volume) of national forests. As a representative example of the conventional yield table, a larch stand in Shinshu District (developed by Kazumi MINE, 1956) is shown in Table 1. The purpose of this yield table is to estimate the growth curve of the "normal" forest stand managed by the "normal method". In other words, it is the function of the yield table to explain the growth process of a stand in a specific state and under specific management.

This can be explained by one curve for one growth process of one forest stand in the space with variables such as stand age, volume, tree height and density. In addition, even in the case of the multi-dimensional space of the growth process with variables of diameter, it may show one line displaying one pattern of one forest stand. This is called the yield table of the first generation (Fig.1).

This yield table does not explain anything about the stand in a state deviating from the line or about growth in cases deviating from this management. However, in actual planning practice, useful information has been obtained practically for this line-adjacent stand or similar management by using this line (SUGAHARA 1973). In calculating the standard cutting volume of national forest, a conventional yield table has been adjusted and used to show the average growth process of numerous and varied forest stands actually in existence.
Table 1 Format of conventional yield table

\begin{tabular}{|c|c|c|c|c|c|c|c|}
\hline \multirow{3}{*}{ site } & \multirow{3}{*}{$\begin{array}{c}\text { age } \\
\text { (year) }\end{array}$} & \multicolumn{4}{|c|}{ major tree } & \multirow{2}{*}{\multicolumn{2}{|c|}{$\frac{\text { sub tree }}{1 \text { ha }}$}} \\
\hline & & \multirow{2}{*}{$\begin{array}{c}\text { average } \\
\text { height } \\
\text { (m) }\end{array}$} & \multirow{2}{*}{\begin{tabular}{|c} 
average \\
diameter \\
$(\mathrm{cm})$
\end{tabular}} & \multicolumn{2}{|c|}{1 ha } & & \\
\hline & & & & $\begin{array}{c}\text { tree } \\
\text { number }\end{array}$ & $\begin{array}{c}\text { volume } \\
\left(\mathrm{m}^{3}\right)\end{array}$ & $\begin{array}{c}\text { tree } \\
\text { number }\end{array}$ & $\begin{array}{c}\text { volume } \\
\left(\mathrm{m}^{3}\right)\end{array}$ \\
\hline \multirow{9}{*}{ I } & 10 & 8.4 & 9.6 & 1,390 & 45.8 & 810 & 11.1 \\
\hline & 15 & 12.5 & 15.3 & 1,040 & 120.0 & 350 & 18.2 \\
\hline & 20 & 16.3 & 19.0 & 796 & 187.0 & 244 & 31.5 \\
\hline & 25 & 19.0 & 21.9 & 632 & 225.8 & 164 & 35.1 \\
\hline & 30 & 21.5 & 24.7 & 514 & 256.7 & 118 & 37.1 \\
\hline & 35 & 23.6 & 27.5 & 429 & 286.0 & 85 & 37.4 \\
\hline & 40 & 25.4 & 30.2 & 362 & 311.1 & 67 & 39.1 \\
\hline & 50 & 28.2 & 35.2 & 374 & 353.3 & 38 & 35.1 \\
\hline & 60 & 29.5 & 39.6 & 226 & 383.6 & 20 & 25.8 \\
\hline
\end{tabular}

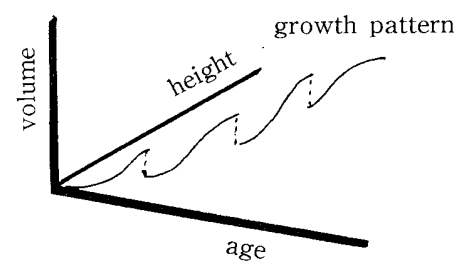

Fig. 1 Line information of stand growth process by the conventional yield table

\section{FOREST STAND DENSITY-CONTROL DIAGRAM}

\section{Yield Table of the Second Generation}

A growth diagram of the stand prepared with the density effect of the stand as a basis is called a "forest stand density-control diagram". This diagram shows relationships corresponding to stand density, volume, tree height and diameter in the growth process of the stand on the plane(ANDO 1968).

The following characteristics may be noted regarding application of this diagram: (i) it is possible to calculate the values of other variables from two variables as diameter and volume can be estimated when stand height and density are given, and (ii) it can estimate the yield in the case of various density-controls. It is possible to estimate the relation of each correspondence by drawing 4 variables together on the two dimensional plane. The greatest feature of this density-control diagram is the function explaining the growth process corresponding to various density controls under a certain condition, that is, an explanation is given for the growth process as one phase in the space with axes of density, volume and tree height.

The conventional yield table of the first generation was line information on growth, while this density-control 


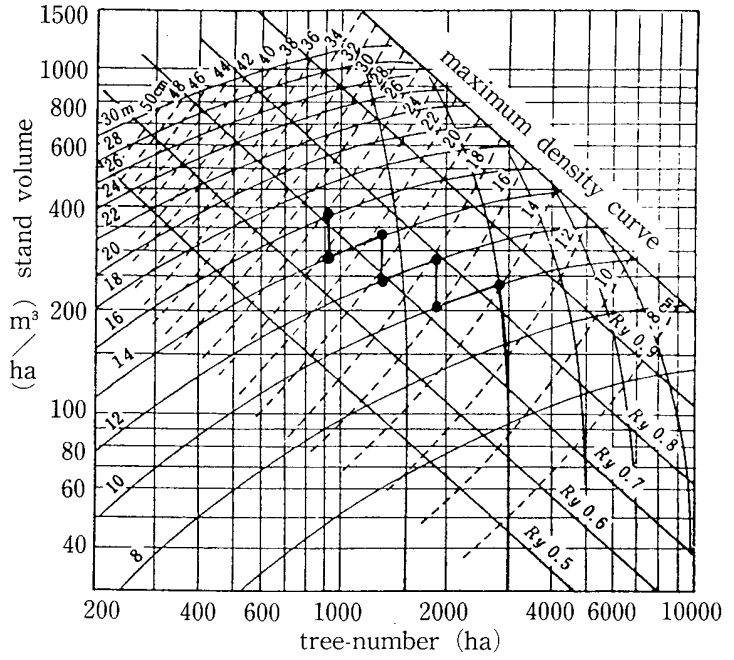

Fig. 2 Format of the stand density-control diagram

diagram would be plane information on growth, and is called the "yield table of the second generation". There are restrictions such as the difficulty in logic to draw 4 variables on one plane as a diagram, and the fact that stand age should be obtained secondarily. However, this densitycontrol diagram has played a vital role in formulating policies on thinning in national and private forests.

\section{SYSTEM YIELD TABLE}

\section{Yield Table of the Third Generation}

The basic characteristic of the system yield table is that it is a computer-program with an algorithm to estimate the growth process in the future in cases of various types of management for the forest stand under various conditions (KONOHIRA 1992, 1995). Evaluation shall be made for the function level of the system yield table by explaining the condition of the forest stand, management method and growth process. Functions are explained by the following 4 items (Table 2), and levels are divided into 2 parts from the evaluating viewpoint (Table 3 ).

Using the above 4 evaluating items, definitions were made for each level according to the function necessary for the system yield table. Whereas, the system yield table means the explanation of the concept discriminating the conventional yield table, its basic function is, as mentioned above, said to be a "computer-program with an algorithm for estimating growth process in the future in cases of various types of management for the forest stand under various conditions". A stricter definition may not be necessary at present. With the development of further higher level programs, its definition will be enlarged, and there is
Table 2 Evaluating items of the system yield table

(1) Quantity and quality of information on estimating forest stand condition, management and growth (information quantity).

(2) Range of applicable forest stand (applicable range).

(3) Usability of the system yield table program (easiness of use).

(4) Rationality of growth model used for estimation (logic).

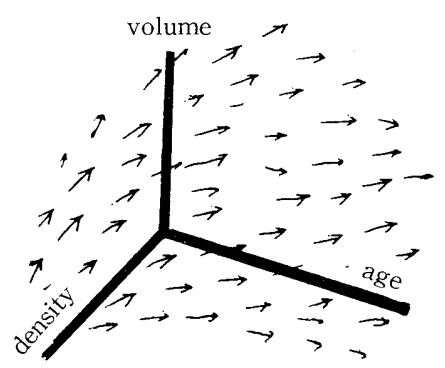

Fig. 3 Concept of multi-dimentional space information on stand growth process by the system yield table.

high possibility of the development of a yield table of the 4 th generation.

For the time being, such mixed items as: "having a function just like the system yield table", "lacking parts even though it is the system yield table", or "having the complete function of the system yield table" may exist. These programs will survive if they are useful, and disappear if not in the field of forest management.

The conventional yield table has been called the "first generation yield table" with the display of one line in the forest stand growth. The forest stand density-control diagram is called the "second generation" meaning it displays one phase in the space with variables such as density, volume and tree height. The system yield table can express countless growth processes in countless forest stands in a multi-dimensional space formed by variables including tree diameter, height, volume, density, tree age, thus, it is called the third generation yield table to indicate the whole space. 
Table 3 Levels and functions of the system yield table

\begin{tabular}{|c|c|c|}
\hline $\begin{array}{l}\text { Evaluating } \\
\text { item }\end{array}$ & First level & Second level \\
\hline $\begin{array}{l}\text { Information } \\
\text { quantity }\end{array}$ & $\begin{array}{l}\text { Growth of stand is estimated by representative } \\
\text { value or mean value of growing stock, volume, tree } \\
\text { height, diameter, density (stand information). } \\
\text { With stand age as variables, estimation is made for } \\
\text { the condition of stand at an age in the future } \\
\text { (optional stand age). } \\
\text { There is no restriction on stand age or initial condi- } \\
\text { tion of stand starting the estimate (freedom of ini- } \\
\text { tial value). } \\
\text { As a management method, density-control is con- } \\
\text { ducted by thinning and planting tree numbers, and } \\
\text { thinning is carried out at the optional time (thin- } \\
\text { ning). }\end{array}$ & $\begin{array}{l}\text { Single tree information composing the stand is esti- } \\
\text { mated (single tree information). } \\
\text { As contents of thinning, not only the thinning rate } \\
\text { but selecting method are freely handled (compli- } \\
\text { cated thinning). } \\
\text { Estimation is made for the effect and influence of } \\
\text { management other than thinning, e.g. selective cut- } \\
\text { ting, prunning, vine cutting, fertilizing, damage by } \\
\text { storms, damage by insects (complicated manage- } \\
\text { ment method). }\end{array}$ \\
\hline $\begin{array}{l}\text { Applicable } \\
\text { range }\end{array}$ & $\begin{array}{l}\text { Applied for single tree species, same aged planta- } \\
\text { tions (simple plantation). } \\
\text { Applied for specific district (specific area). } \\
\text { Applied for specific tree species (specific species). } \\
\text { Applied for various site (site). }\end{array}$ & $\begin{array}{l}\text { Applied for two-layer or multi-storied stand (non } \\
\text { clear cutting management stand). } \\
\text { Applied for natural forest or selective cutting forest } \\
\text { (natural forest). } \\
\text { Easy adjustment of parameter to apply for wider } \\
\text { area or more tree species. (flexibility of applica- } \\
\text { tion). } \\
\text { Applied for density-control or long rotation manage- } \\
\text { ment not existing at present (long rotation). }\end{array}$ \\
\hline $\begin{array}{l}\text { Easiness of } \\
\text { use }\end{array}$ & $\begin{array}{l}\text { Simple and easy operation and environment for full } \\
\text { use with limited knowledge of the computer (easy } \\
\text { use). } \\
\text { Easy understanding with constant indication for use } \\
\text { by program of conversation type (dialogue func- } \\
\text { tion) } \\
\text { Free format with less input data. Effective use of } \\
\text { existing data file (free format, data base, easy } \\
\text { input). } \\
\text { Easy re-trial or repeating calculation (simulation } \\
\text { function). } \\
\text { Display of estimating value with easily understand- } \\
\text { able type (freedom of output). }\end{array}$ & $\begin{array}{l}\text { Estimable from other data in case of shortage of } \\
\text { input data (default function). } \\
\text { Earlier reach to the target in repeating the trial } \\
\text { calculation (learning function). } \\
\text { Improvement of estimating accuracy by adding the } \\
\text { field survey data (self-growth function). } \\
\text { Easy connection to other systems such as forest } \\
\text { register, allowable cut calculation, harvest and sale } \\
\text { (systematization function). } \\
\text { Easy reforming of program for specific necessity by } \\
\text { specific user (customizing function). } \\
\text { Guide and instruction available for trouble during } \\
\text { operation (helping function). } \\
\text { Diagramming of output result (graphic function). } \\
\text { High compatibility of hardware with software } \\
\text { (compatibility). }\end{array}$ \\
\hline$\overline{\text { Logic }}$ & $\begin{array}{l}\text { Prospect of no serious error in the range of approval } \\
\text { in practice with no complete rationality by many } \\
\text { assumptions (rationality). } \\
\text { Some reliable numerical calculation by experience } \\
\text { or existing data without conformable model (cred- } \\
\text { ible). } \\
\text { Distinction with explanation of calculating algorithm } \\
\text { (algorithm). }\end{array}$ & $\begin{array}{l}\text { Assembled with widely recognized growth formula } \\
\text { (growth model). } \\
\text { Consistent rationality to the applications among } \\
\text { variables (logic consistence). } \\
\text { Automatic checking test with clear explanation of } \\
\text { calculating algorithm (autocheck function). } \\
\text { Detection of abnormal value with prevention of } \\
\text { runaway (self control function) }\end{array}$ \\
\hline
\end{tabular}




\section{LITERATURE CITED}

Ando, T., (1968): Forest stand density-control. Norinshuppan, Tokyo, $246 \mathrm{pp}$

Konohira,Y., (1992): System yield table. Reasearch report for the Ministry of Education, Tokyo, 138pp

Konohira,Y., (1995) : System yield table programs. Research report for the Ministry of Education, Tokyo, 198pp

Miura,I., (1967): Handbook for foresters. Rinyakosaikai, Tokyo, 839 pp

Mizuta,T., (1977): Theory and practice of thinning. Sobun, Tokyo, 69 pp

Nagumo,H. and Minowa,M., (1990): Forest Mensuration. Chikyusha, Tokyo, 243pp

Sugahara,S., (1973): Larch forestry today. Ringyo-keizai-shinbun Press. Nagano, 236pp

(Received 2 June 1995)

(Accepted 30 June 1995) 